\title{
Producing of Biodegradable Plastic Films from Un-marketable Potato Tubers
}

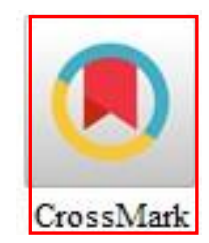

\section{Aya MM Kobash"1, Mobarak M Mostafa', Fathi AAHassan², Ashrf A Anwar'}

1- Agricultural Engineering Department, Faculty of Agriculture, Ain Shams Univerasity, PO Box 68, Hadayek Shubra 11241, Cairo, Egypt

2- Bio-Engineering Department, Agricultural Engineering Research Institute" AENRI“, Agricultural Research Center, Giza, Egypt

* Corresponding author: Aya.m.mahmoud@agr.asu.edu.eg

DOI:10.21608/ajs.2021.92037.1409

Received 13 September, 2021 ; Accepted 7 December, 2021

\section{Keywords:}

Solid waste, Agro waste, Starch based plastic, Oil based plastic, Unmarketable potato tubers

\begin{abstract}
This study was conducted to reduce the volume of solid wastes by using unmarketable potato tubers for producing biodegradable plastic films to be substitute oil based plastics "OBP" which is often not biodegradable. Starch based plastic films "SBP" were produced with different concentrations of glycerol $(5,10,15,20,25,30,99.5 \% \mathrm{v} / \mathrm{v})$ as a plasticizer. The physical properties of SBP including thickness, density, water absorption, biodegradability, were studied, as well as mechanical properties including tensile strength, modulus of elasticity, elongation $\%$ and the required energy for firm were also investigated compared with OBP samples. The results showed that the maximum value of extracted starch was $13.5 \%$ obtained by blending potato tubers. SBP films with elevated glycerol concentration increased the sample thickness but decreased its density. Glycerol 20\% gave the best flexible compact structure SBP films. Average thickness and density SBP film (20\% glycerol) were $0.25 \mathrm{~mm}$ and $80.11 \mathrm{Kg} / \mathrm{m}^{3}$ respectively. Meanwhile, the average thickness and density for OBP films were $0.41 \mathrm{~mm}$ and $24.39 \mathrm{Kg} / \mathrm{m}^{3}$ respectively. The rate of mass loss of SBP films with $20 \%$ glycerol concentration was $72 \%$ after 96 days while the rate of mass loss for OBP films is neglect able. Consumed energy for firm were 44.05 and 31.06 N. mm.
\end{abstract}

\section{Introduction}

Egypt is from the countries which could not manage solid wastes in properly methods that have harmful effects on health and environment. Egypt produces annually about 90 million tons of solid wastes which equal 55.000 tons per day. (Hashem 2020). The mass generation rate of solid waste in Egypt estimated 0.6 to $\mathrm{kg} /$ day/capita, with an annual increasing of $3.4 \%$, (Kaza et al 2018). One ton of transferring solid wastes costs nearly 100 L.E in Egypt governorates from collec- tion till disposal. The average cost recovery is about $70 \mathrm{~L} . \mathrm{E} / \mathrm{ton}$ and the total cost recovery is around 200 million L.E./year. (EEAA 2005). The type of wastes determines the selling price of sorted wastes per tons. Mass of solid waste final destination is $5 \%$ land filled, 9\% composted, $83.5 \%$ open dumped, $2.5 \%$ recycled.

Many of researchers mentioned that the importance of agricultural wastes management and convert it into valuable and useful products (Gupta et al 2019, Maji et al 2020, Duque et al 2020, He et al 2019, Fareed et al 2020, Maraveas 2020). The reduction of wastes defined by (Elbasiouny et al 2020, Khan and Faisal 
2020) that the reduction of wastes means the reduction of the weight, the concept of "Recycle" means re-use wastes of materials again.

(Das et al 2019, De clercq et al 2017) observed that our oceans polluted due to increasing consumption of conventional plastic, because most countriesdon't have a suitable management of plastic wastes system. (Hong et al 1999) reported that the big difference between conventional plastic and bio plastic is that bio plastic made from renewable sources are biodegradable. To get rid oil based plastic is extremely difficult when burning them gives off toxic chemicals such as dioxins. (Mohee and Unmar 2007) indicated that, bio plastics reduce carbon footprint and do not require fossil fuels like oil based plastics. Also have the potential to reduce the volume of municipal waste generated. Bio plastics can be composted, thus it can be collected together with food craps or yard waste and diverted to compost heaps which can be used to feed the soil and grow more plants. (Zawya2011). Around 6\% of the world oil supply is used in the production of plastics and it is mainly used for the plastic packaging and vehicle assembly and in construction. (Bayer et al 2014). Biodegradable plastic was produced from spinach stems, parsley, rice hulls and cocoa pod husks have mechanical properties comparable to conventional plastics according to (Moore 2014). Using starch in the manufacturing of bio plastics will reduce the levels of environmental pollution. Conventional plastic takes 3.2 metric tons of carbon dioxide but bio plastic takes only 0.8 metric tons of carbon dioxide. (Kim 2003) showed that, in order to reduce the rate of environmental pollution, non- biodegradable plastics can be replaced by bio plastics which can be made from potato starch. (Potatopro 2014) mentioned that, Egypt is one of the top 20 producers of potato worldwide and the top largest producer in Africa. So the objective of the present study is to find innovative solutions to reduce the accumulation of municipal wastes and ameliorate the quality of life in urban and rural villages via sustainable. To achieve this goal, the following steps were taken:

1. Utilizing some starch rich agro waste in the production of a biodegradable starch based plastics, unmarketable potato tuber.

2. Analyze the physical and mechanical properties of starch based plastic compared with traditional plastics.

\section{Materials and Methods}

The procedures for extracting starch from unmarketable potato tubers, preparing starch based bioplastic samples and testing their physical and mechanical properties were carried out during the period from April 2020 until February 2021 in laboratory of the Biochemistry Department and the Laboratory of the Agricultural Engineering Department - Faculty of Agriculture - Ain Shams University.

\subsection{Potato tuber}

Unmarketable potato tubers (Solanum tuberosum, cv. Spunta.) obtained from Osiem's region vegetable local market, Giza governorate. As mentioned by (Ereifej et al 1997). The chemical composition of potato tuber cv. Spunta was presented in Table 1.

\subsection{Chemicals}

The chemical materials used for preparation Starch-based bio plastic film were $0.1 \mathrm{M}$ HCL, $0.1 \mathrm{M}$ $\mathrm{Na} \mathrm{OH}$ and $99.5 \%$ glycerol obtained from ElGomhoria company located in 23 El sawahst. ElAmiria region, Cairo, Egypt. Glycerol is an additive that softens the material. It's function as plasticizer used in the bio plastic film production. It is a colorless, odorless, viscous liquid and has a high boiling point and freezes to form a paste.

\subsection{Synthetic oil based plastic}

The conventional oil based plastic films samples that were used for comparison with the prepared starch-based bio-plastic samples obtained from Hyma Plastic Company. 22 Al Obor Gardens, Salah Salem st., Nasser City, Cairo. Oil based plastic films samples with dimensions $28 * 22 \mathrm{~cm}$ with different thickness "500:2000 $\mu \mathrm{m}$ " with high-density polyethylene (HDPE) $15 \%$ and low density polyethylene (LDPE) $85 \%$. The oil based plastic samples is called as (OBP).

\subsection{Extraction of starch}

Starch extraction process from unmarketable potato tubers carried out according to (Salisu et al 2013) and (Oluwasina et al 2016) which involves after removing damaged parts of potato tubers infected with fungal or bacterial diseases, the unmarketable potato tubers were properly washed with water to remove soil particles before being peeled, it was cut into slices of different thickness, and part of it was also ground in the blender in the presence of water. The homogenates 
Table 1. Chemical composition and total solids contents ofpotato cultivars Spunta (dry weight basis)

\begin{tabular}{|c|c|c|c|c|c|c|}
\hline Contents & Carbohydrates & Total solids & Fibers & Ash & Protein & Fats \\
\hline Amount $\%$ & 76.6 & $20,7 \%$ & 8.2 & 3.58 & 11.3 & 0,35 \\
\hline
\end{tabular}

were mixed with distilled water [homogenate: water (1:5)] and then sieved. The resultant slurry was allowed to settle for $6 \mathrm{~h}$ before the supernatant was decanted. The sediment was washed several times by re-suspending in distilled water and precipitating. The starch mash was dried at $50^{\circ} \mathrm{C}$ to constant weight. The starch was then sieved (sieve size of 249-212 $\mathrm{Mm}$ ). The sieved material was packed in an air tight plastic and stored at room temperature for further use. The stages of potato extraction process from unmarketable potato tubers were presented in Fig $\mathbf{1}$.

\subsection{Production steps of bio plastic films from unmarketable potato tubers}

The methodology of producing the bio plastics is carried out according to (Keshav 2016). Put 15 $\mathrm{g}$ potato starch for $150 \mathrm{ml}$ distilled water in beaker $500 \mathrm{ml}$ and put $18 \mathrm{ml}$ of $0.1 \mathrm{M} \mathrm{HCL}$ in the mixture and the same amount of $0.1 \mathrm{M} \mathrm{NaOH}$ was added for neutralization and put $12 \mathrm{ml}$ of Glycerol in each treatment as a plasticizer and operate the magnetic stirrer at $100^{\circ} \mathrm{C}$ and let stirring at 200 r.p.m and The mixture was heated for about 10 minutes, after 1 hour the mixture turned into opaque gel. This gel was spread on trays. The trays of samples were leaved to dry at temperatures of laboratory and the samples after drying convert into plastic sheets. Production steps of starch based plastic films from unmarketable potato tuber were presented in Fig 2.

\subsection{Test Variables}

\subsubsection{Starch extraction variables}

The starch was extracted from un-marketable potato tubers after cutting into slices of different thickness as follows:

$$
\text { (0 mm "blended", } 1.5 \mathrm{~mm}, 2 \mathrm{~mm}, 4 \mathrm{~mm})
$$

\subsubsection{Starch based plastic production varia- bles}

Starch based plastic films samples were prepared using seven concentrations of glycerol as follows:
$(5 \%, 10 \%, 15 \%, 20 \%, 25 \%, 30 \%, 99.5 \%)$

\subsection{Samples preparation for tests}

To compare physical and mechanical properties of the produced starch based plastic "SBP" samples by all tested glycerol concentrations with conventional oil based plastic "OBP" films. The films from "SBP" and "OBP" were cut into samples with dimensions of 115 $\mathrm{mm}$ long and $32 \mathrm{~mm}$ wide strips. In order to make reliable comparisons between different samples, it is necessary to standardize the humidity conditions, as well as the temperature, to which specimens of these materials are subjected prior to and during testing. All bio plastic films were conditioned prior to subject them to physical and mechanical tests according to Standard method. Films used for testing Tensile Strength (TS) were stored at controlled conditions "desiccators" $\left(25^{\circ} \mathrm{C}\right.$ and $75 \%$ of relative humidity) for 48 hours before measurements.

\subsection{Physical properties}

\subsubsection{Thickness}

The thickness of starch based plastic samples was measured by using a digital vernier caliper. The thickness was calculated during tensile test and the statistical values of the sample thickness for each treatment were recorded. Determinations biodegradability and mechanical properties were by using the average of thickness equal $0.25 \mathrm{~mm}$.

\subsubsection{Density " $\rho$ "}

The density of the starch based bio plastic "SBP" samples with dimension $\left(\mathrm{A}^{*} \mathrm{~T}\right) \mathrm{mm}^{3}$ was calculated directly from measuring the samples mass and volume for each glycerol concentration.

Density " $\rho "=\frac{\mathrm{m}}{A \times T} \quad\left(\mathrm{~kg} / \mathrm{m}^{3}\right)$

Where, $\boldsymbol{\rho}=$ density, $\left(\mathrm{kg} / \mathrm{m}^{3}\right), \mathrm{m}=$ mass of the sample $(\mathrm{kg}), \mathrm{A}=$ area $=$ Length $*$ Width $\left(\mathrm{mm}^{2}\right)$

and $\mathrm{T}=$ thickness of the film (mm). 


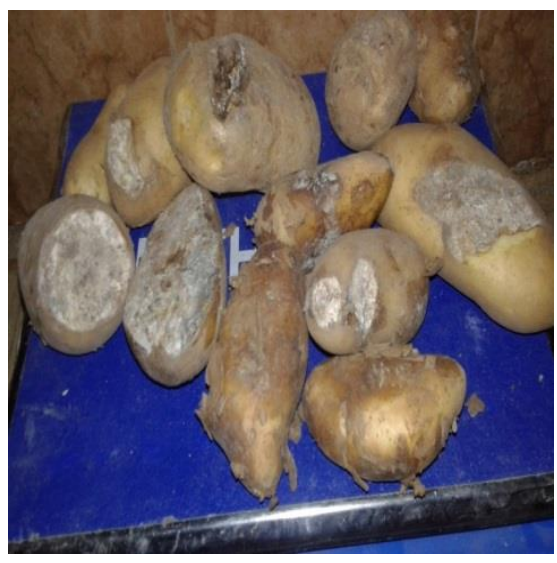

(a). Unmarketable potato tuber

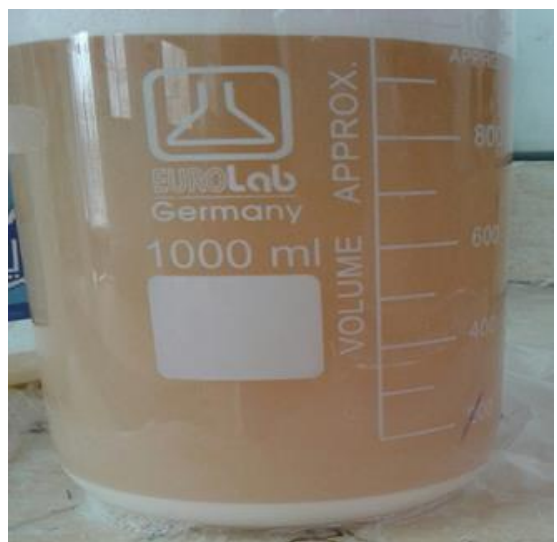

(d). Filtration of starch for 6 hours

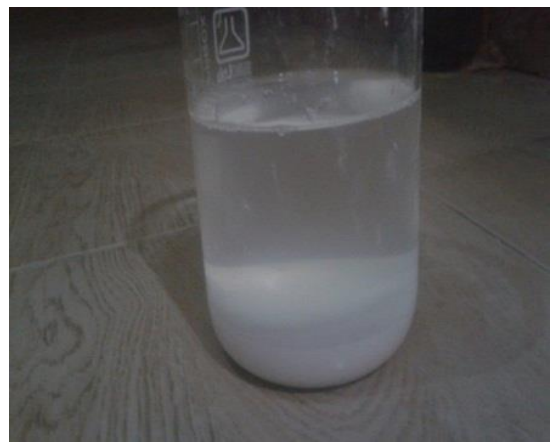

(g). Sedimentation starch after water extraction

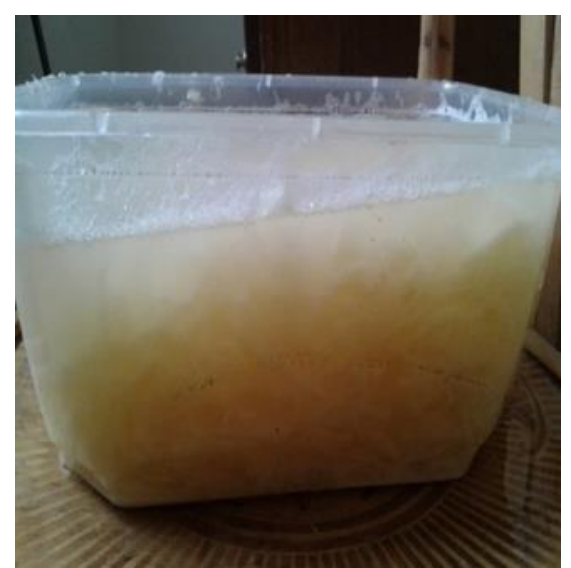

(b). Soak the grated orblended potato slices in water for 6 hours

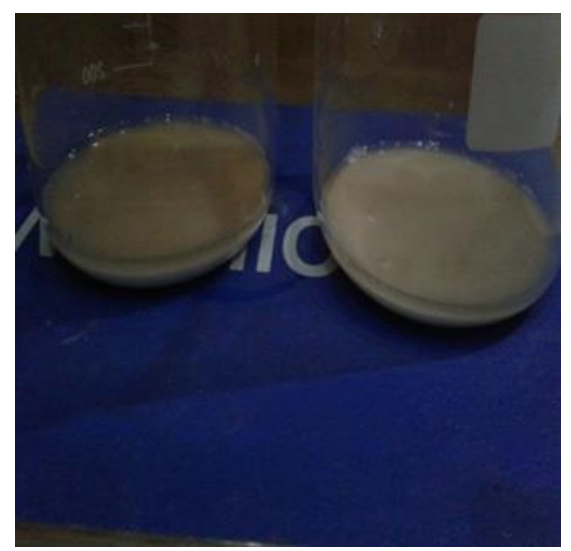

(e). Removing of dark water

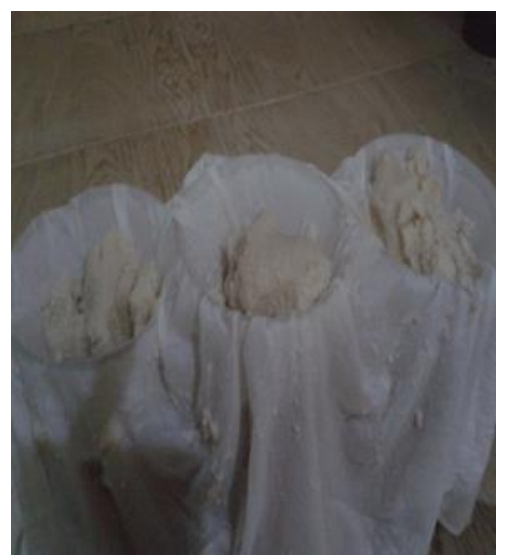

(c). Double layered cheesecloth for filtration

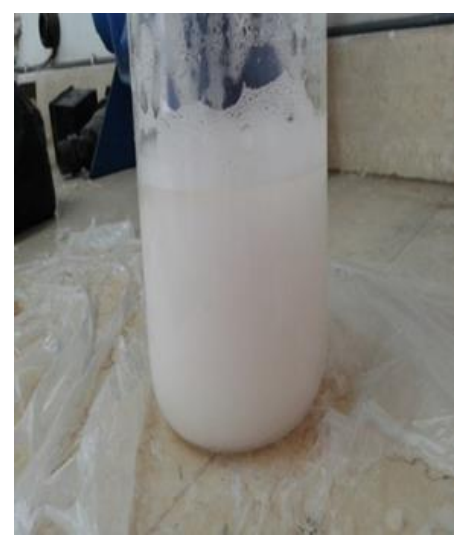

(f). Adding amount of water for the starch and remaining 6 hour for starch sedimentation

Fig 1. Stages of Starch extraction process from unmarketable potato tubers 


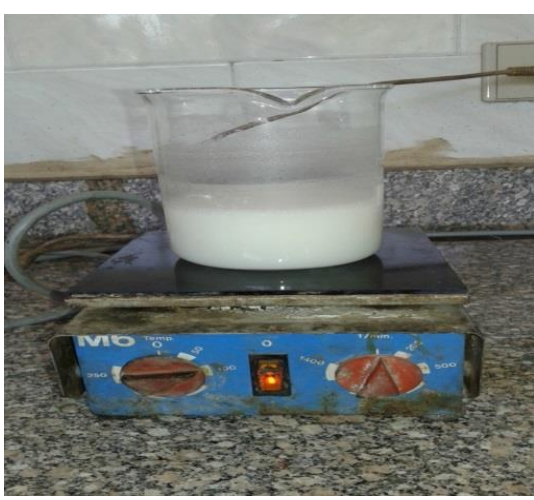

(a). Operating of magnetic stirrer to prepare bio plastic sample

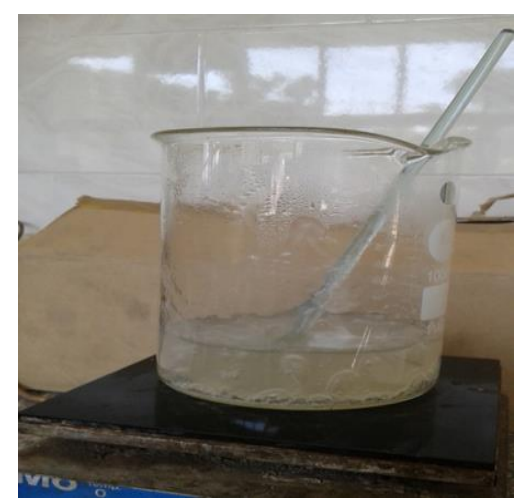

(b). Turning the mixture to opaque gel

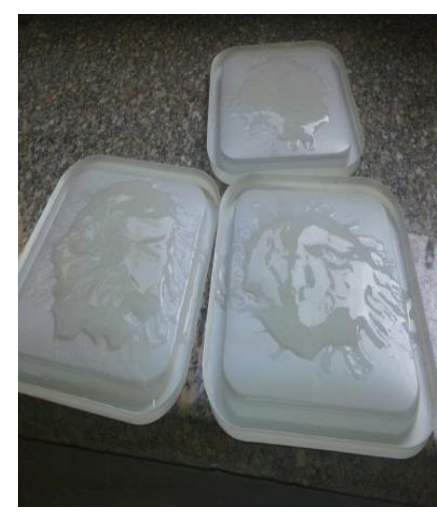

(c). Separate the gel and left it to dry

Fig 2. Production steps of starch based plastic film samples from potato tuber

\subsubsection{Water Absorption capacity (W.A.C)}

The water absorption capacity was measured according to D570 (ASTM 1998). Two types of plastic samples which were starch based plastic "SBP" and oil based plastic "OBP" having the same surface-area "1 x 2 cm2". Samples of the two types of plastic were submerged into a beaker containing $60 \mathrm{~mL}$ of distilled water " $\mathrm{pH} \mathrm{7,} \mathrm{room}$ temperature " $25^{\circ} \mathrm{C}$ ". After two hours, the samples were removed from beaker then water was removed from the surface these samples by a paper towel, the samples were weighed with digital balance $0.01 \mathrm{~g}$ accuracy, and re-submerged into the water. Then were weighed again after each $2 \mathrm{~h}$ for a long $24 \mathrm{~h}$ following the same procedure. All measurements were performed in triplicates. The percentage of water absorption of initial weight was determined from the following equation:

(W.A.C $)=\frac{(\text { Mass of wet film }- \text { Mass of dry film) }}{\text { Mass of dry film }} \times 100(\%)$

\subsubsection{Biodegradability Test}

The Biodegradability of the two types of plastic samples SBP and OBP was determined on the basis of mass loss index. By adding $220 \mathrm{~g}$ wetted soil in a glass beaker on high $5 \mathrm{~cm}$ at laboratory scale. The sample was $\left(2 \times 2 \mathrm{~cm}^{2}\right)$ constant mass (Mo). The sample was exited from beaker and was removed soil particles conjoined this sample then was dried in the sun for $3 \mathrm{~h}$. Data was recorded every $72 \mathrm{~h}$ to measure the mass $\mathrm{M}_{\mathrm{f}}$. this method was repeated every $72 \mathrm{~h}$ and every time was put $10 \mathrm{ml}$ water for soil before burial the sample. Percentage of mass loss $\left(\mathrm{M}_{\mathrm{L}}\right)$ was calculated from the following equation.

$$
\mathrm{M}_{\mathrm{L}}(\%)=\frac{\left(\mathrm{M}-\mathrm{M}_{\mathrm{F}}\right)}{\mathrm{M}_{\odot}} \times 100
$$

Where, $\mathrm{M}_{\mathrm{L}}=$ Mass Loss, $(\%), \mathrm{M}_{\mathrm{O}}=$ Initial mass of sample before burial $(\mathrm{g}), \mathrm{M}_{\mathrm{f}}=$ Final mass of sample after burial, (g).

\subsection{Mechanical properties}

Tensile strength, modulus of elasticity "young, s modulus" (E), elongation and firm test for the "SBP" and "OBP" samples were determined at ambient condition $25^{\circ} \mathrm{C}$ and $\mathrm{RH} 48 \%$, according to the method D882-18(ASTM 2018). Using a computer type bench top materials tensile testing machine (Tinius Olsen model H5ks - USA). The films were cut into samples of $32 \mathrm{~mm}$ wide and $115 \mathrm{~mm}$ long. The plastic samples were fixed between two jaws (upper jaw moving, lower jaws fixed) with the rate of speed was $1 \mathrm{~mm} / \mathrm{s}$. The data were recorded and the mechanical parameters were calculated as follows:

\subsubsection{Tensile strength (MPa)}

Tensile strength obtained from stress-strain curves by using the following equation:

$$
\text { Tensile strength }(\mathrm{MPa})=\frac{\text { (Maximum force) }}{\text { Initialcross section area }}
$$

\subsubsection{Elongation at break $(\%)$}

Elongation at break is an indication of plastics flexibility and is expressed as a percentage, obtained from stress- strain curves by using the following equation:

Elongation at break $(\%)=\frac{\text { Deformation }}{\text { Initiallength }} \times 100 \ldots$ 


\subsubsection{Modulus of elasticity (E)}

Modulus of elasticity was calculated using the following equation:

$$
\mathrm{E}(\mathrm{MPa})=\frac{\text { stress }}{\text { strain }}
$$

\subsubsection{Consumed energy for firm (N.mm)}

The consumed energy for firm was calculated from the area under the curve.

\subsection{Statistical Analysis}

To select the recommended glycerol's concentration for producing bio plastic films, Glycerol was used in seven levels of $5,10,15,20,25,30$ and $99.5 \%$, where each level represents three treatment. The collected data were statistically analyzed to get values of (max, min, average, standard deviation $(\delta)$ (STDV), and coefficient of variance (C.V) using Microsoft office Excel Program.

\section{Results and Discussions}

\subsection{Starch extraction}

Fig 3 Represents the effect of potato slice thickness on the percentage of extracted starch. The recorded data reviled that; the extracted starch \% from unmarketable potato tuber increased with decreased the slice thickness. The maximum value of extracted starch was $13.5 \%$ when blending the unmarketable potato tuber. Meanwhile, the minimum value of extracted starch was $4.2 \%$ when the slice thickness was 4 $\mathrm{mm}$.

\subsection{Physical properties}

\subsubsection{Thickness, $\mathrm{mm}$}

Table 2 Represents the SBP samples thickness statistical values (Max., Min, Average, STDEV and coefficient of variation) with different glycerol concentration compared with OBP samples. It is clear that; the thickness of SBP samples slightly affected by the Glycerol concentration, where the average thickness increased from 0.22 to 0.25 and $0.31 \mathrm{~mm}$ with increased glycerol concentration from 5 to 20 and $30 \%$ respectively. Meanwhile OBP average thickness was, $0.41 \mathrm{~mm}$.

\subsubsection{Density " $\rho$ " $\mathrm{Kg} / \mathrm{m}^{3}$}

Table 3 Represents the SBP samples density statistical values (Max, Min, Average, STDEV and coefficient of variation) with different glycerol concentration compared with OBP samples. It is clear that, the density of SBP samples slightly affected by the glycerol concentration, where the average density decreased from 91.06 to 80.11 and $63.85 \mathrm{Kg} / \mathrm{m}^{3}$ with increased glycerol concentration from 5 to 20 and 30 $\%$ respectively. Meanwhile OBP average density was, $24.39 \mathrm{Kg} / \mathrm{m}^{3}$.

\subsubsection{Water Absorption \%}

Fig 4 Represents the water absorption capacity \% of starch based plastic films "SBP" $20 \%$ glycerol, compared with oil based plastic "OBP" 15\% HDPE. It is clear that, the water absorption of SBP samples were $49.11 \%$ within two hours and $83.33 \%$ within 24 hours. While the absorption capacity for OBP samples was $35.11 \%$. It means that SBP films at $20 \%$ glycerol have the higher of ability to absorb water because of the hydrophobicity of the glycerol, Whereas the higher of ability to absorb water made SBP probably does not use in the food industry. Thus, the possibility of a proposal put some additives for SBP samples to increase resistance of water absorption.

\subsubsection{Biodegradability}

Fig 5 Represents the mass loss \% "Biodegradability" of starch based plastic "SBP" $20 \%$ glycerol, compared with oil based plastic "OBP" $15 \%$ HDPE. It is clear that the biodegradability of two type plastic films buried in moist soil during 96 days was that, within four weeks, the SBP samples lost $30 \%$ from their mass "biodegraded" and this value increased to $72 \%$ after 96 day. On the other hand, within the investigation time 96 days OBP doesn't show any considerable mass loss value "non-degraded". So that, the higher ability of SBP films to biodegraded make it suitable material for the manufacture of single-use packaging products that in need locally and globally as an ecofriendly product instead of oil based plastic.

\subsection{Mechanical properties}

\subsubsection{Tensile strength}

Fig 6 Represents effect of glycerol concentration on tensile strength of starch based plastic "SBP" compared with oil based plastic "OBP" films " $15 \%$ HDPE". It is clear that, tensile strength increased with 


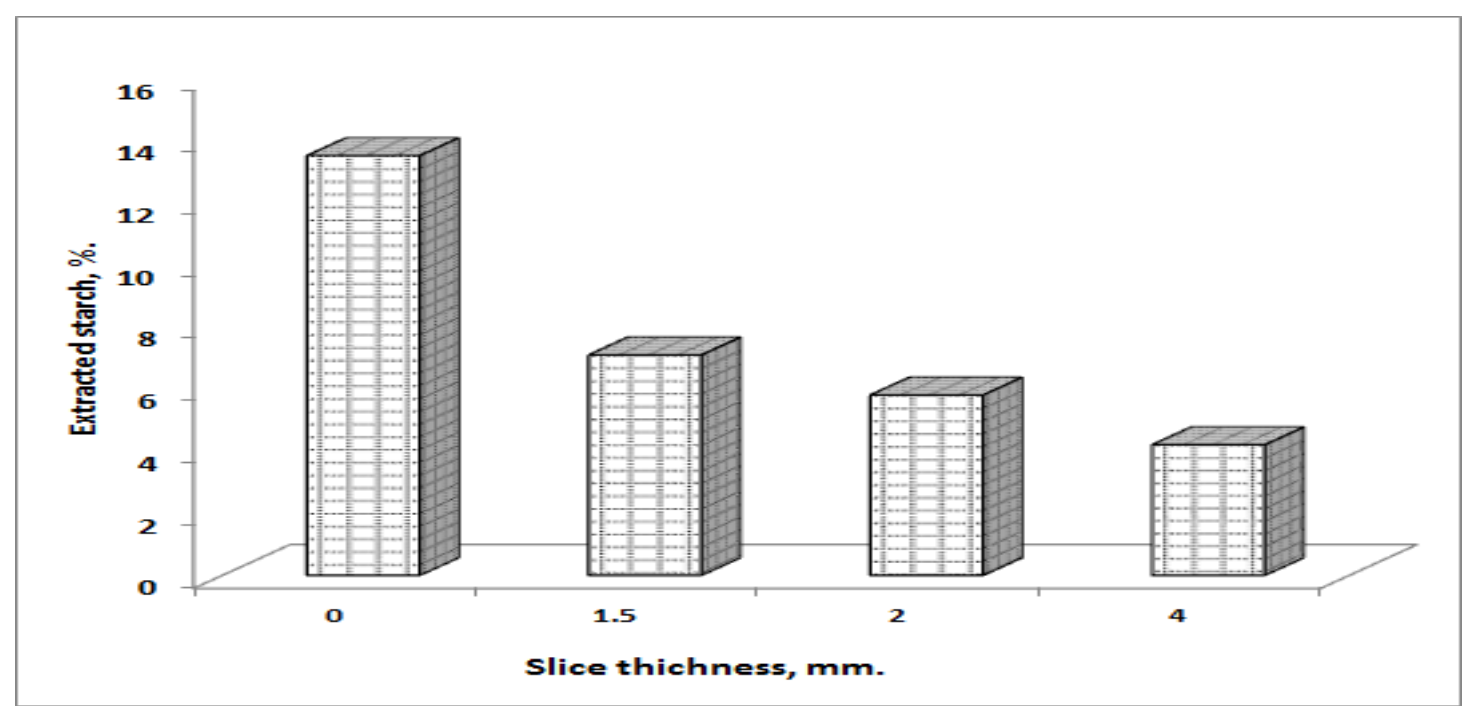

Fig 3. The effect of potato slice thickness on the percentage of extracted starch

Table 2. Effect of glycerol concentration on SBP films thickness statistical values (Max, Min, Average, Stander deviation and coefficient of variation) compared with OBP films

\begin{tabular}{|c|c|c|c|c|c|c|c|c|}
\hline \multirow{4}{*}{$\begin{array}{c}\text { Statistical } \\
\text { values }\end{array}$} & \multicolumn{7}{|c|}{ Starch based plastic "SBP" } & \multirow{3}{*}{$\begin{array}{c}\text { Oil based } \\
\text { plastic. } \\
\text { "OBP" }\end{array}$} \\
\hline & \multicolumn{7}{|c|}{ Glycerol conc. $\%$} & \\
\hline & 5 & 10 & 15 & 20 & 25 & 30 & 99.5 & \\
\hline & \multicolumn{8}{|c|}{ Thickness (mm) } \\
\hline Max. & 0.23 & 0.25 & 0.26 & 0.26 & 0.27 & 0.29 & 0.34 & 0.41 \\
\hline Min. & 0.21 & 0.23 & 0.23 & 0.24 & 0.24 & 0.25 & 0.29 & 0.41 \\
\hline Average & 0.22 & 0.24 & 0.24 & 0.25 & 0.25 & 0.27 & 0.31 & 0.41 \\
\hline SD & 0.01 & 0.01 & 0.02 & 0.01 & 0.02 & 0.02 & 0.03 & 0 \\
\hline C.V. & 0.06 & 0.05 & 0.08 & 0.05 & 0.08 & 0.1 & 0.1 & 0 \\
\hline
\end{tabular}

Table 3. Effect of glycerol concentration on SBP films density statistical values (Max, Min, Average, STDEV and coefficient of variation) compared with OBP films.

\begin{tabular}{|c|c|c|c|c|c|c|c|c|}
\hline \multirow{3}{*}{$\begin{array}{c}\text { Statistical } \\
\text { values }\end{array}$} & \multicolumn{7}{|c|}{ Starch based plastic "SBP" } & \multirow{3}{*}{$\begin{array}{c}\text { Oil based } \\
\text { plastic. } \\
\text { "OBP" }\end{array}$} \\
\hline & \multicolumn{7}{|c|}{ Glycerol conc. \% } & \\
\hline & 5 & 10 & 15 & 20 & 25 & 30 & 99.5 & \\
\hline & \multicolumn{8}{|c|}{ Density $\left(\mathrm{Kg} / \mathrm{m}^{3}\right)$} \\
\hline Max. & 95.23 & 86.9 & 86.9 & 83.33 & 83.33 & 80 & 68.9 & 24.39 \\
\hline Min. & 86.9 & 80 & 76.9 & 76.9 & 74.07 & 68.9 & 58.8 & 24.39 \\
\hline Average & 91.06 & 83.45 & 81.9 & 80.11 & 78.7 & 74.45 & 63.85 & 24.39 \\
\hline SD & 5.84 & 4.8 & 7.07 & 4.5 & 6.5 & 7.8 & 7.14 & 0 \\
\hline C.V. & 0.06 & 0.05 & 0.08 & 0.05 & 0.08 & 0.1 & 0.1 & 0 \\
\hline
\end{tabular}




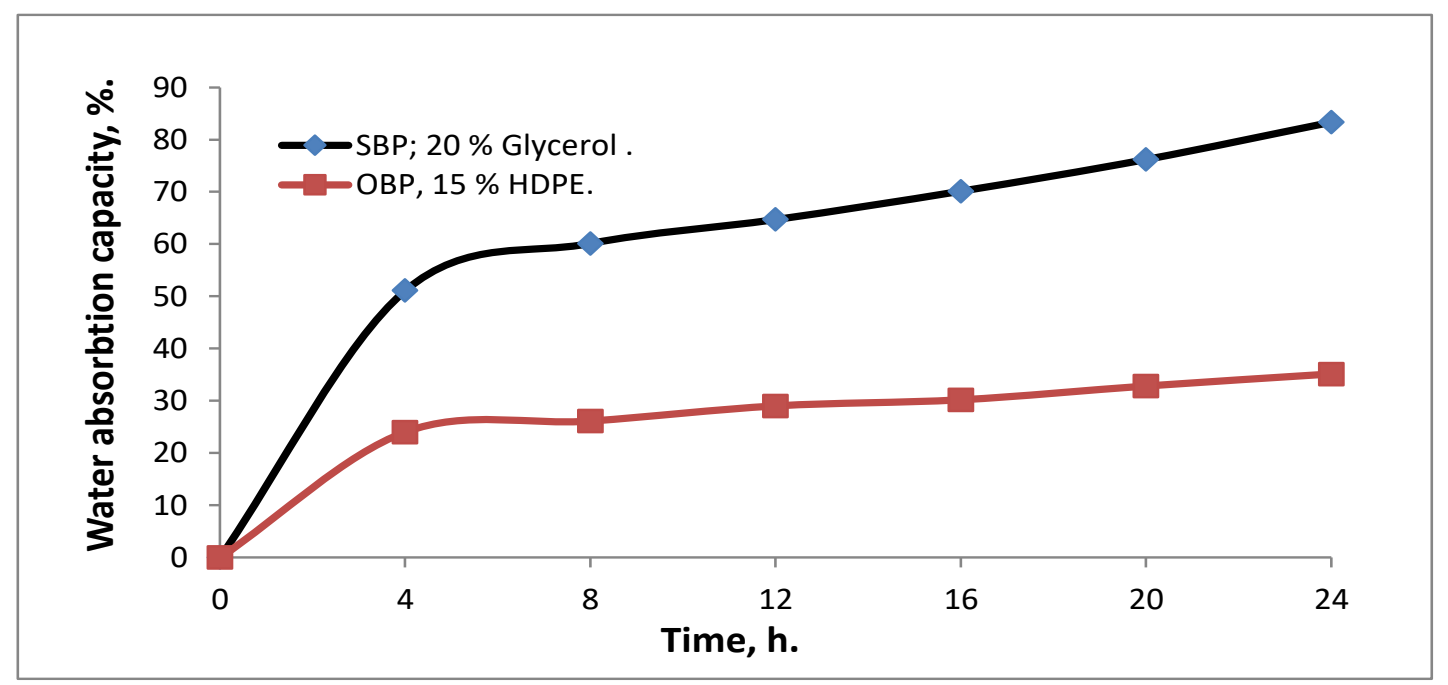

Fig 4. Water absorption capacity \% of starch based plastic "SBP" compared with oil based plastic "OBP"

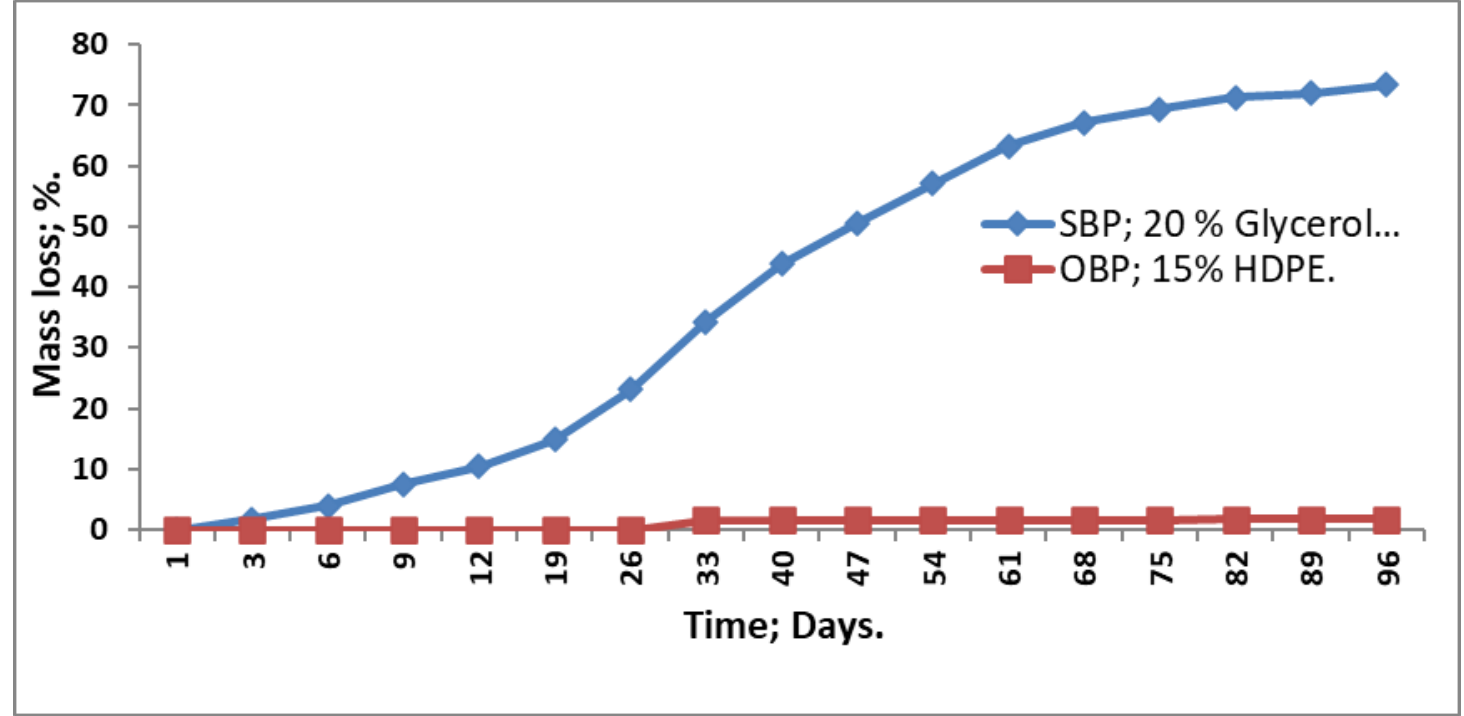

Fig 5. Mass loss \% "Biodegradability" of starch based plastic "SBP $20 \%$ glycerol concentration" compared with oil based plastic "OBP 15\% HDPE".

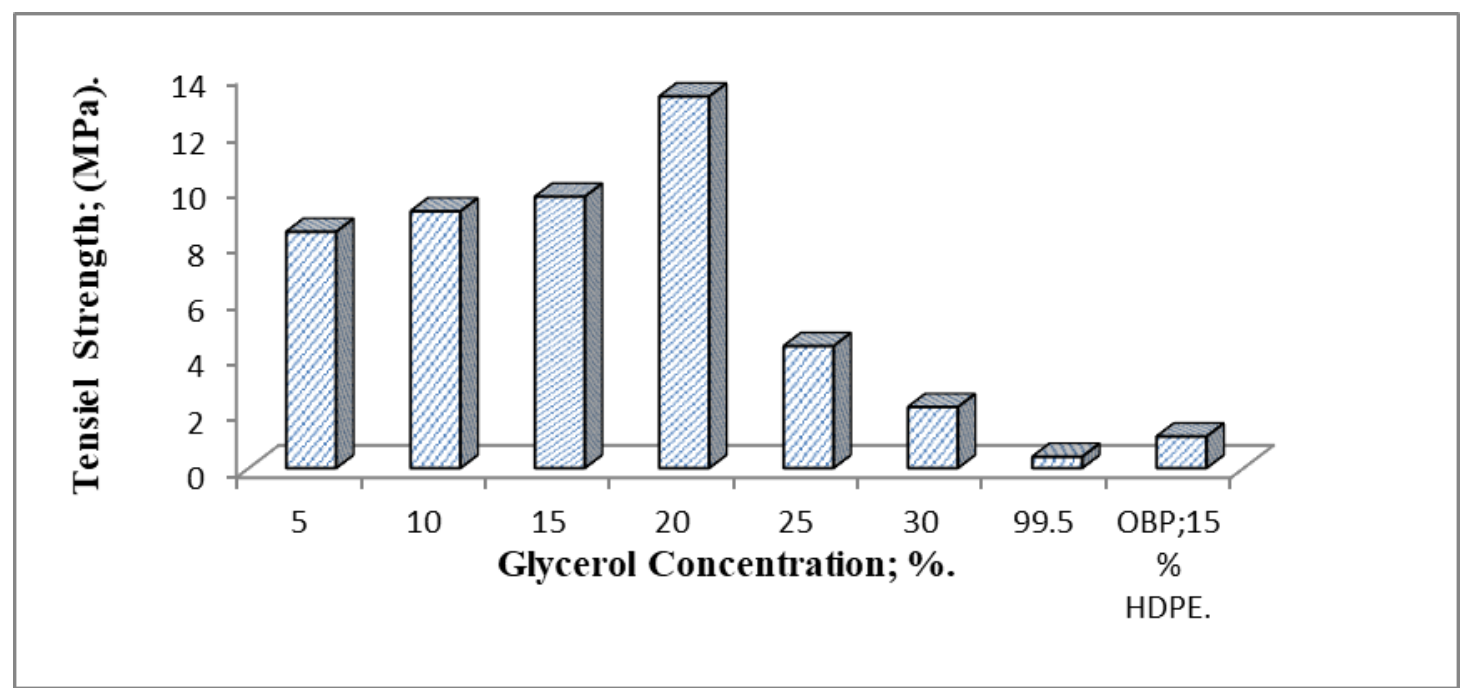

Fig 6. Effect of glycerol concentrations on tensile strength of starch based plastic "SBP" compared with oil based plastic "OBP" films " $15 \%$ HDPE". 
increasing of glycerol concentration from 5 to $20 \%$ then reduced to the lowest value with glycerol concentration of $99.5 \%$. The maximum and minimum tensile strength were $(13.23$ to $0.4 \mathrm{MPa})$ recorded with glycerol concentration (20 and 99.5\%) respectively. Meanwhile the tensile strength recorded with oil based plastic "OBP" films was $1.12 \mathrm{MPa}$. The value of tensile strength increased with increasing of glycerol concentration from 5 to $20 \%$ and decreased with increasing glycerol concentration more than $20 \%$.

\subsubsection{Modulus of Elasticity}

Fig 7 Represents the effect of glycerol concentration on modulus of elasticity of "SBP" concentration of $99.5 \%$. The maximum compared with "OBP" films. Modulus of elasticity. It is clear that; modulus of elasticity increased with increasing of glycerol concentration from 5 to $20 \%$, then reduced to the lowest value with glycerol and minimum modulus of elasticity were (1556.73 and 7.41 $\mathrm{MPa}$ ) recorded with glycerol concentration (20 and 99.5\%) respectively. Meanwhile modulus of elasticity recorded with oil based plastic "OBP" films was $44.97 \mathrm{MPa}$. It means that, the Starch based plastic "SBP" sample bearing strength was higher than the value recorded with "OBP" films.

\subsubsection{Elongation at break}

Fig 8 Represents the effect of glycerol concentration on elongation\% of starch based plastic "SBP" compared with oil based plastic "OBP" films. It is clear that, elongation behavior increased with increasing of glycerol concentration. The maximum and minimum elongation SBP films were (106.43 and $100.45 \%)$ recorded with glycerol concentration 5 and 99.5\% respectively. Meanwhile the corresponding value of elongation\% for oil based plastic "OBP" films was $107.5 \%$.

\subsubsection{Firm force}

Fig 9 Represents the effect of concentration on firm force of "SBP" compared with "OBP" films. It is clear that; firm force for oil based plastic "OBP" films was $1.08 \mathrm{~N}$, while SBP $20 \%$ glycerol firmed by 0.916 $\mathrm{N}$.

\subsubsection{Consumed energy during firm}

Fig 10 and 11 Represent the consumed energy during firm the starch based plastic "SBP" and oil based plastic "OBP" films; the area under the curve equal consumed energy during firm test. The recorded data reviled that; the consumed energy for firm strength with starch based plastic "SBP" was 44.05 N.mm, Meanwhile the corresponding value recorded with oil based plastic "OBP" was 31.06 N.mm.

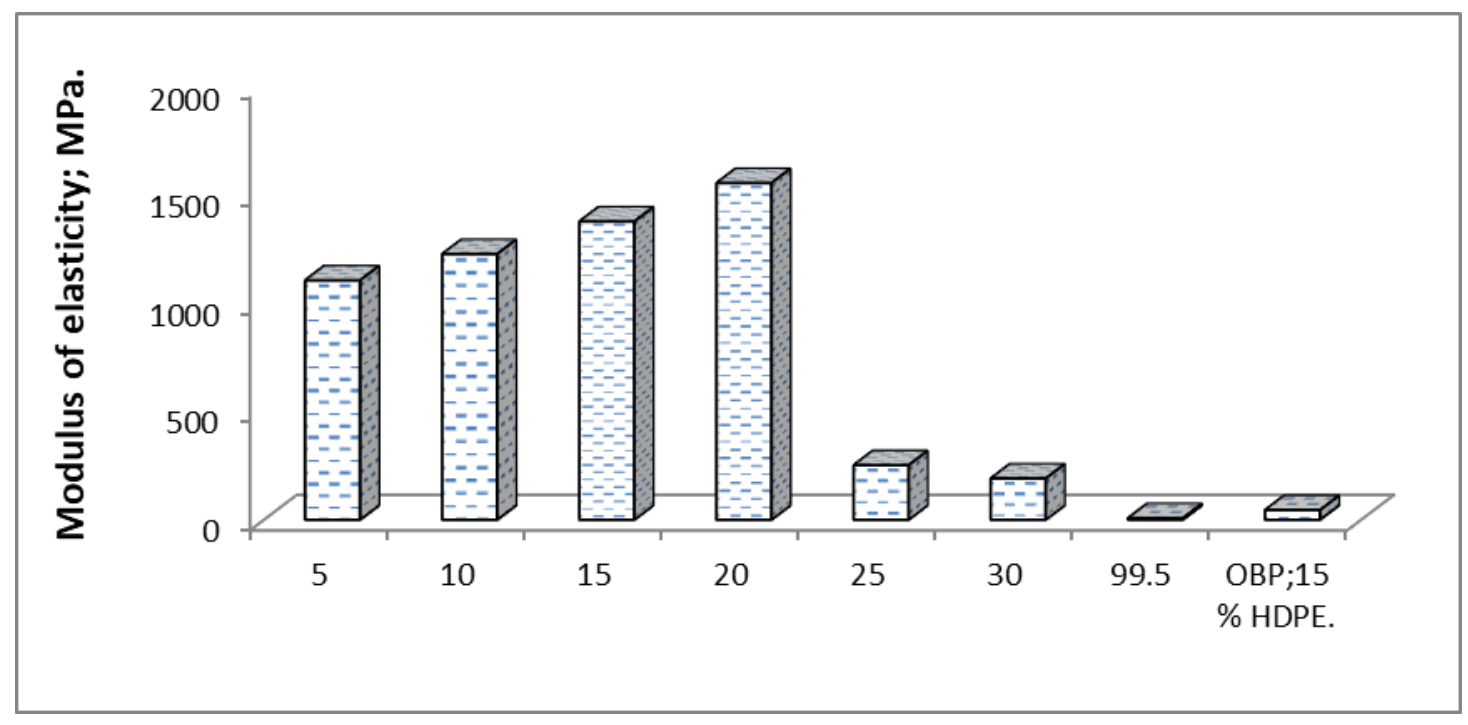

Fig 7. The effect of glycerol concentrations on modulus of elasticity of "SBP" compared with oil based plastic “OBP” films 


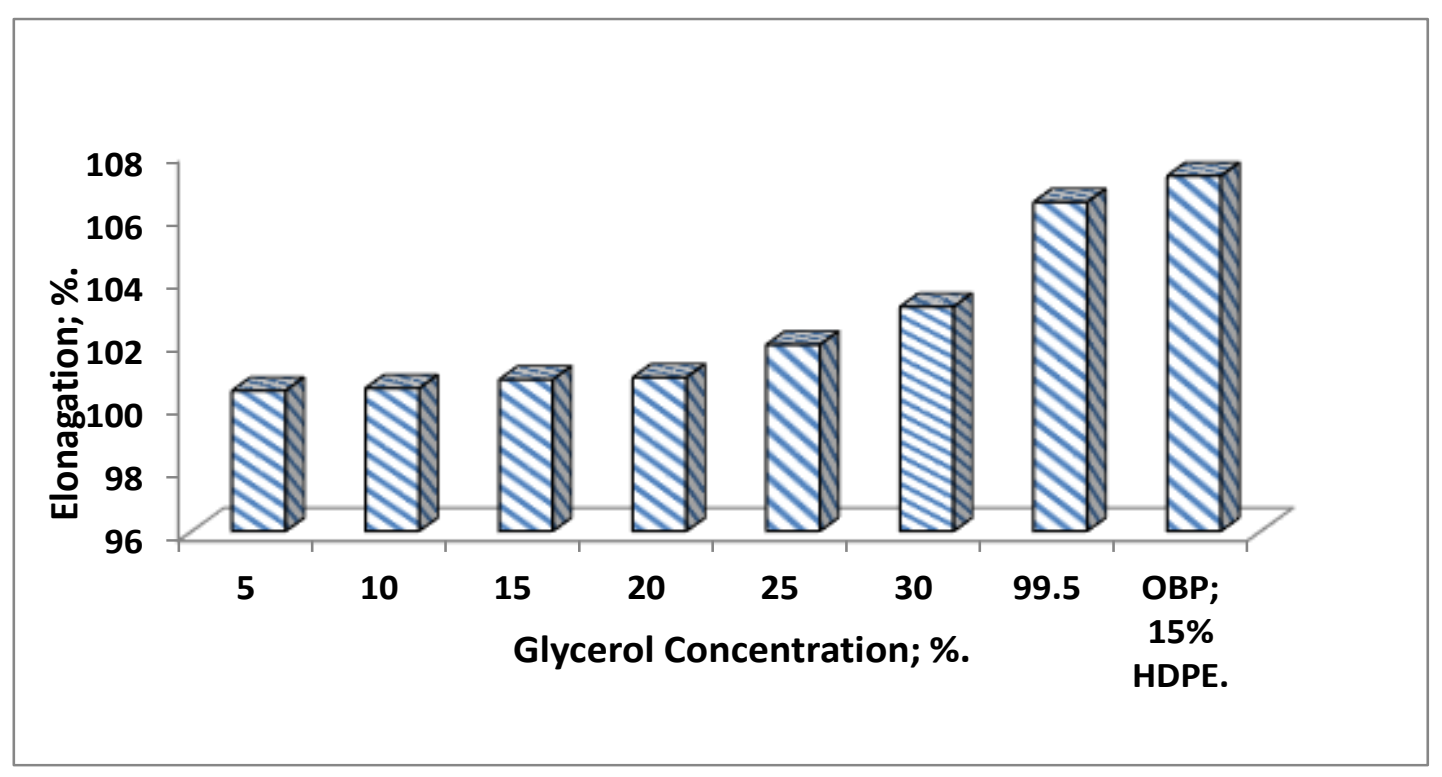

Fig 8. The effect of concentrations glycerol on elongation \% of starch based plastic "SBP" compared with oil based plastic "OBP” films

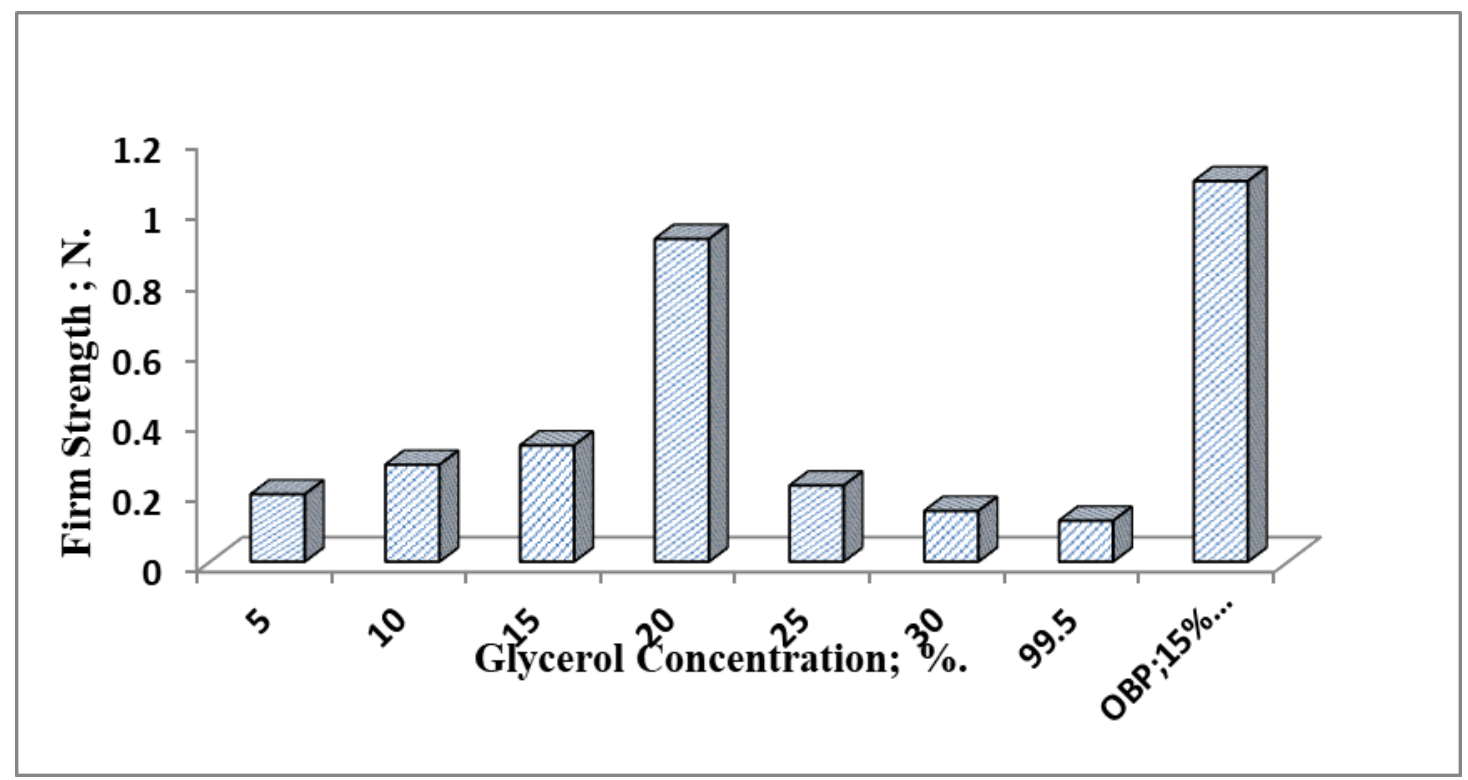

Fig 9. The effect of glycerol concentration on firm force of starch based plastic "SBP" compared with oil based plastic "OBP" films 

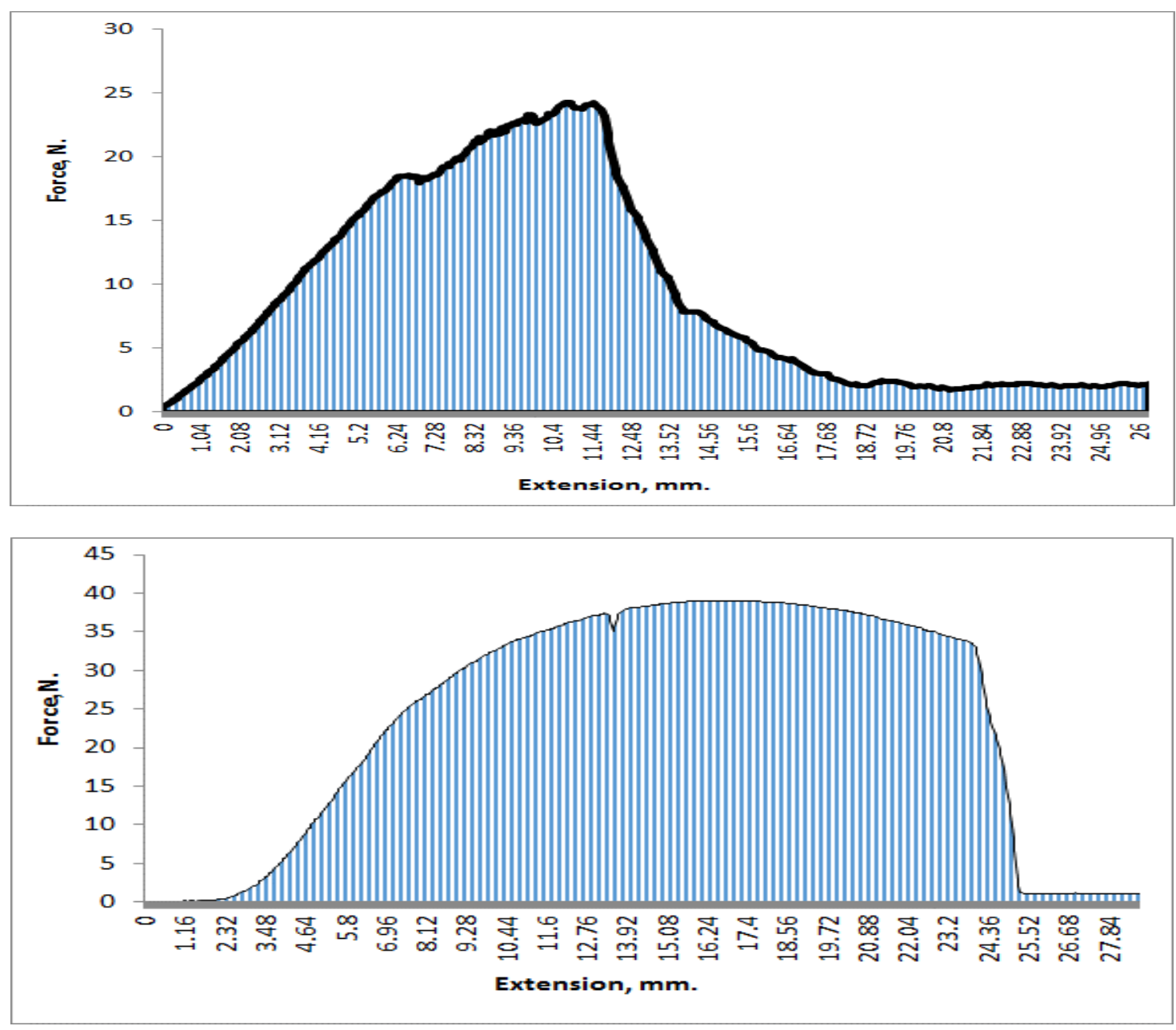

Fig 10, Fig 11. Consumed energy during firm with SBP and OBP films respectively

\section{Conclusions}

This study succeeded in production starch based plastic by using extracted starch from Unmarketable potato tubers plasticized with any polyol such as glycerol. This idea may consider as an innovative method that will reduce the accumulation of MSW and petroleum based plastic pollution. It was found that, blending potato tubers gave a maximum value of extracted starch. As far SBP physical properties, glycerol concentration affected the thickness and density of the films. Increasing the glycerol concentration leads to increasing the thickness, while the density decreased. SBP films tensile strength and elongation that are two major mechanical properties for the plastic within range to make it has market potential. However, the higher of ability to absorb water made SBP probably does not use in the food industry, therefore the possibility of a proposal put some additives to SBP samples to increase re- sistance of water absorption to be suitable for one time use packaging materials, since it is characterized by rapid decomposition. Therefore, producing starch based biodegradable plastic from un-marketable potato tuber will reduce the accumulation of MSW and petroleum based plastic waste enhances rural economic, quality of life and ecosystem in general.

\section{References}

ASTM (2018) Standard test methods for tensile properties of thin plastic sheeting. Designation: D882-18. Annual book of ASTM standards, Philadelphia, PA: ASTM.

https://standards.globalspec.com/std/13050669/astm$\underline{\mathrm{d} 882}$

ASTM (1998) Standard Test Method for Water Absorption of Plastics. Designation: D570-98. ASTM International, 100 Barr Harbor Drive, PO Box C700, West Conshohocken, PA 19428-2959, United States. 
Bayer IS, Guzman-Puyol S, Heredia-Guerrero JA (2014) Direct Transformation of Edible Vegetable Waste into Bio plastics. Macromolecules. 47, 5135-5143. DOI:10.1021/ma5008557

Chua H, Yu P HF, Ma C K (1999) Accumulation of biopolymers in activated sludge biomass. Applied Biochemistry and Biotechnology, 78, $389-$ 399. DOI:10, 1385/ABAB:78:1-3:389.

Das S, Lee SH, Kumar P, Kim KH, Lee SS, Bhattacharya SS (2019) Solid waste management: scope and the challenge of sustainability. Journal of Cleaner Production, 228, 658-678. https://doi.org/10.1016/j.jclepro.2019.04.323

De Clercq D, Wen Z, Gottfried O, Schmidt F, Fei F (2017) A review of global strategies promoting the conversion of food waste to bioenergy via anaerobic digestion, Renewable and Sustainable Energy Reviews, 79, 204-221.

DOI:10.1016/j.rser.2017.05.047

Duque-Acevedo M, Belmonte L, Joaquín CF, Camacho F (2020) Agricultural waste: Review of the evolution, approaches and perspectives on alternative uses, Global Ecology and Conservation, https://doi.org/10.1016/j.gecco.2020.e00902

EEAA (2005) Strategic Framework for Enhancing Solid Waste Recycling in Egypt. Egyptian Environmental Affairs Agency, Regional Solid Waste Management Project (METAP),

http://www.eeaa.gov.eg.

Elbasiouny H, Elbanna BA, Al-Najoli E, Alsherief A, Negm S, Abou El-Nour E, Nofal A, Sharabash S (2020) Agricultural Waste Management for Climate Change Mitigation: Some Implications to Egypt. Waste Management in MENA Regions, pp. 149-169. Cham, Springer International Publishing. (also available at: http://link.springer.com/10.1007/978-3-030$\underline{18350-9 \quad 8)}$

Ereifej KI, Shibli RA, Ajlouni MM, Hussein A (1997) Chemical composition variations of tissues and processing characteristics in ten potato cultivars grown in Jordan, American potato Journal 74, 23-30.

Fareed A, Zaidi SBA, Ahmad N, Hafeez I, Ahmad MF (2020) Use of agricultural waste ashes in asphalt binder and mixture: A sustainable solution to waste management. Construction and Building Materials, 259, 120575. DOI:10.1016/j.conbuildmat.2020.120575
Gupta C, Prakash D, Gupta S, Nazareno MA (2019) Role of Vermicomposting in Agricultural Waste Management. S. Shah et al (eds.), Sustainable Green Technologies for Environmental Management, pp 283-295. Springer Nature Singapore Pte Ltd.

https://doi.org/10.1007/978-981-13-2772-8_15

Hashem E (2020) Factors affecting Solid Waste Recycling in Egypt. Journal of International Business and Economics, 8, 1-21.

https://doi.org/10.15640/jibe.v8n1a1

He C, Sampers I, Raes K (2019) Dietary fiber concentrates recovered from agro-industrial by-products: Functional properties and application as physical carriers for probiotics. Food Hydrocolloids 111, 106175. https://doi.org/10.1016/j.foodhyd.2020.106175

Kaza S, Yao L, Bhada-Tata P, Van Woerden F (2018) What a waste 2.0. A GlobalSnapshotof Solid Waste Management to 2050.World Bank, Washington, DC. https://doi.org/10.1596/978-1-4648-1329-0.

Kim DH, Na SK, Park JS (2003) Preparation and characterization of modified Starch-based plastic Film Reinforced with Short pulp fiber. I.Structural properties. Journal of Applied Polymer Science, 88, 21002107. https://doi.org/10.1002/app.11630.

Maji S, Dwivedi DH, Singh N, Kishor S, Gond M (2020) Agricultural Waste: Its Impact on Environment and Management Approaches. In: R.N. Bharagava (ed.), Emerging Eco-friendly Green Technologies for Wastewater Treatment, Microorganisms for Sustainability 18 ,

https://link.springer.com/chapter/10.1007/978-981-15$\underline{1390-9 \_15}$

Maraveas C (2020) Production of Sustainable and Biodegradable Polymers from Agricultural Waste. Polymers (Basel) 12, 1127.

DOI:10.3390/ polym12051127.

Mohee R, Unmar G (2007) Determining biodegradability of plastic materials under controlled nature composting environments. Waste Management 27, 1486-93. DOI:10.1016/j.wasman.2006.07.023

Moore CJ (2014) Probing the horrors of the Great Pacific Garbage Patch, New York Times.

Oluwasina OO, Umunna QC, Olusegun SJ, Wahab O (2016) Songklanakarin Journal Science Technology, 38, 349-355.

Potatopro (2014) Egypt: Potato statics. [online] Available at: https://www.potatopro.com/egypt/potatostatistics, updated on 14 August 2018. 


\section{Arab Univ J Agric Sci (2021) 29 (3) 845-857}

Salisu AAH, Musa H, Abba AA, Kogo J (2013) Preparation and characterization of dialdehyde starch and itscross-linking with copper (II) ion. Journal of Chemical and Pharmaceutical Research. 5, 153-158.

SoomareeK (2016) Production of potato starch based bioplastic, Thesis for: Chemical Engineering Dep., Faculty of Engineering, University of Mauritius.
Zawya (2011) Global plastic production grew over 500 percent over the last 30 years (online) Available at:

http://www.zawya.com/story.cfm/sidZAWYA201005 05063554/Global\%20plastic\%20production\%20grew \%20over\%20500\%20per\%20cent\%20over\%20the\%2 0past $\% 2030 \% 20$ years. Last accessed $15^{\text {th }}$ October 2015. 